\title{
MtDNA Analyses on Hair Samples Confirm Cougar, Puma concolor, Presence in Southern New Brunswick, Eastern Canada
}

\author{
A.-S. Bertrand ${ }^{1}$, S. Kenn ${ }^{2}$, D. Gallant ${ }^{3}$, E. Tremblay ${ }^{3}$, L. Vasseur ${ }^{4}$, and R. WissinK ${ }^{5}$ \\ ${ }^{1}$ Reserva Brasil, Foz do Iguaçu 85851-970 Brazil; e-mail: annesophie@ @eservabrasil.org.br \\ ${ }^{2}$ Ontario Puma Foundation, Beeton, Ontario L0G 1A0 Canada \\ ${ }^{3}$ Kouchibouguac National Park of Canada, Kouchibouguac, New Brunswick E4X 2P1 Canada \\ ${ }^{4}$ Associate Vice-President, Research, Laurentian University, Sudbury, Ontario P3E 2C6 Canada \\ ${ }^{5}$ Fundy National Park of Canada, Alma, New Brunswick E4H 1B4 Canada
}
Bertrand, A.-S., S. Kenn, D. Gallant, E. Tremblay, L. Vasseur, and R. Wissink. 2006. MtDNA analyses on hair samples confirm Cougar, Puma concolor, presence in southern New Brunswick, eastern Canada. Canadian Field-Naturalist 120(4): 438-442.

For the last 40 years, the presence of Cougars (Puma concolor) in eastern Canada has been highly controversial. The purpose of this study was to collect physical evidence of Cougars using a passive detection method. Baited hair-traps combined with camera-traps were installed in New Brunswick and Nova Scotia, Canada. DNA analyses on two hair samples confirmed that the species was present in southern New Brunswick in 2003. A footprint photographed after an observation of a Cougar by reliable observers was examined by experts and was consistent with a Cougar footprint. Additional data are required to determine the status of Cougars in the northeastern part of its historical range.

Key Words: Cougar, Puma concolor, hair-traps, camera-traps, physical evidence, mtDNA analyses, tracks, eastern Canada.

Historically, the Cougar (Puma concolor) was distributed all across the American continent, from southeastern Alaska to southern Argentina and Chile (Parker 1998). It was the most widely distributed terrestrial mammal in the western hemisphere (Godin 1977). The subspecies referred to as Eastern Cougar (Puma concolor couguar) was known to occur in Nova Scotia [NS], New Brunswick [NB], Quebec [QC], Michigan, Tennessee and South Carolina (Goldman 1946). While 32 subspecies were initially listed by Goldman (1946), a recent DNA study by Culver et al. (2000) showed that only six genetically distinguishable subspecies are now believed to occur in the western hemisphere, with only one for North America; i.e., $P$. $c$. couguar. Populations in northeastern America drastically declined at the beginning of the last century (Parker 1998). Weaver et al. (1996) argued that conflicts for resources and land uses may be the main causes of most Cougar extirpation in North America. Previous studies across North America have indicated that road density, urbanization, agriculture and timber harvesting may also limit Cougar expansion (van Dyke et al. 1986; Maehr et al. 2002; Taylor et al. 2002; Dickson et al. 2005).

The status of the Cougar in eastern North America has always been a highly controversial topic (Cumberland and Dempsey 1994). Due to the secretive habits of this species and the highly fragmented regions where few scattered individuals possibly remain, solid evidence (i.e., a dead animal, DNA collected from scat or hair, a clear photograph or indisputable confirmation of authenticated tracks) is difficult to collect, making decision and species-at-risk designation difficult. Prov- incially, Cougars are listed as undetermined in NS, and endangered in NB. At the federal level, the status of the eastern cougar population was changed from endangered to data deficient in 1998 (Scott 1998*). No reliable estimate of the number of Eastern Cougars has ever been made because authentic, scientifically-based evidence is lacking (Cumberland and Dempsey 1994). However, numerous credible sightings and physical evidences have since then reopened the Eastern Cougar debate. An extensive review carried out by the Committee on the Status of Endangered Wildlife in Canada [COSEWIC] in 1978 leaves little doubt as to the historical presence of Cougars in eastern Canada (van Zyll de Jong and van Ingen 1978*). Today, the major concern of provincial wildlife agencies is whether the reported animals are natives or feral escaped or released captives (Scott 1998*).

While extensive, logistically demanding fieldwork is usually required to search for such a wide-ranging species, this paper focuses on new data obtained for NB through non-invasive detection methods (i.e., baited hair-trap and camera-trap).

\section{Material and Methods \\ Study Areas}

This project was conducted in NB and NS with 12 traps set up in three national parks, i.e., Fundy National Park of Canada [FNP], Kouchibouguac National Park of Canada [KNP] in NB, and Cape Breton Highlands National Park of Canada [CBHNP] in NS. Conservation units being the largest wilderness areas available, they are more likely to shelter wide-ranging top predators than urban or agricultural lands. Two additional 


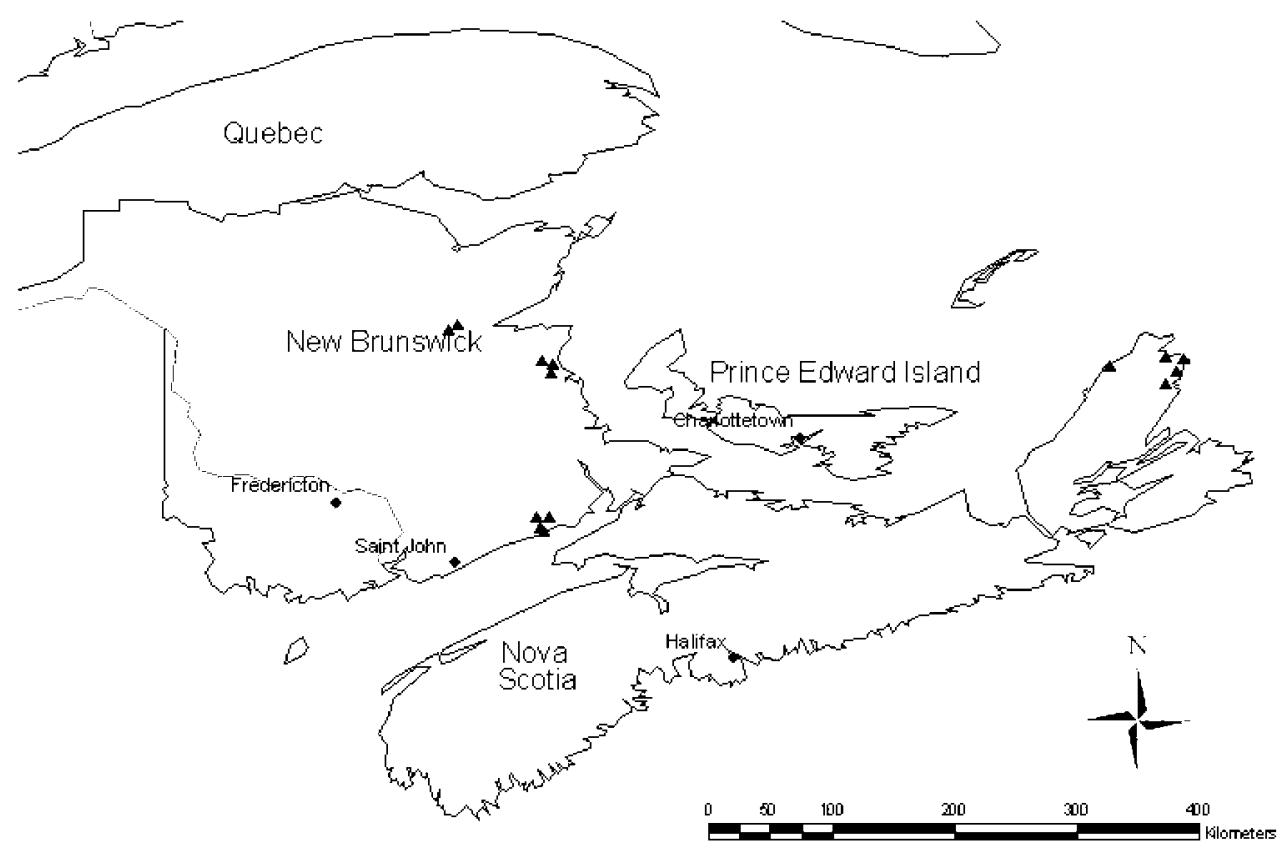

FIGURE 1. Baited hair-trap ( $n=14)$ locations (triangles) in New Brunswick and Nova Scotia, eastern Canada.

traps were installed in remote areas in the Miramichi region (northeastern $\mathrm{NB}$ ) because sightings from reliable observers (biologists and trappers) were frequently reported to provincial wildlife agents. All traps were located according to the most recent credible sighting report or physical evidence (Figure 1). Four traps were set up in FNP in forested habitats on the rolling upland plateau. FNP $\left(205.9 \mathrm{~km}^{2}\right)$ is characteristic of the Maritime Acadian Highlands region and is part of the Appalachian Mountain range (Woodley et al. 1998). Three other traps were installed in KNP $\left(239.2 \mathrm{~km}^{2}\right)$ in northeastern NB. Two traps were installed in coniferous stands, one in a relatively remote area near Black River in KNP's central region, and the other, less than $1 \mathrm{~km}$ from human habitations along the southeastern boundary of the park. The last KNP trap was installed in a hilly mixed wood stand 3 along the Major Kollock creek. Finally, five traps were installed in CBHNP $\left(948.0 \mathrm{~km}^{2}\right)$, the largest protected wilderness area in NS, protecting $20 \%$ of northern Cape Breton. Traps were installed based on recent convincing Cougar sightings in deciduous, mixed wood and dead conifer forests. All trap locations had a closed canopy, an important amount of coarse woody debris or a thick leaf litter, and were close to water sources.

\section{Non-invasive detection techniques}

Field work began during the fall of 2003 . The passive detection methods used entail collecting hairs, tracks, and scats in a non-invasive manner. Baited hair- traps (Figure 2), consisting of 2-m-high posts surrounded by $3 \times 3 \mathrm{~m}^{2}$ squared enclosures, were installed in areas where credible sightings had recently been reported (Figure 1). Two barbed wire strands were stretched around the wooden posts delimiting the enclosure, at $45 \mathrm{~cm}$ and $75 \mathrm{~cm}$ from the ground respectively. This was intended to catch hair as the animal enters the enclosure, attracted by the species-specific lure. Dripping lure (i.e., Cougar urine obtained from captives, sex unknown) was hung inside the perforated central post and fresh lure was added every month.

In 2004, in an attempt to get photographic records of animals entering the enclosure, we equipped each station with a camera-trap unit which consists of either a $35-\mathrm{mm}$ or a digital camera triggered by an infrared motion sensor. Each camera was fastened to a tree near the scent post, at a height of $1.8 \mathrm{~m}$ (Figure 2). Any motion up to $7 \mathrm{~m}$ away within an angle of 120 degrees activated the camera. Traps were checked year-round every 4-5 weeks.

\section{DNA analyses}

Samples were submitted to a sequence-based analysis of 16S mitochondrial DNA (mtDNA; Johnson and O'Brien 1997). DNA was extracted from hair samples using QIAGEN DNeasy Tissue kits. In order to determine whether DNA samples were from felid or other mammal species (i.e., felids, canids, cervids, 4 mustelids, procyonids, and ursids), 300 base pairs of 16S mtDNA were amplified using Polymerase Chain Reaction (PCR). 


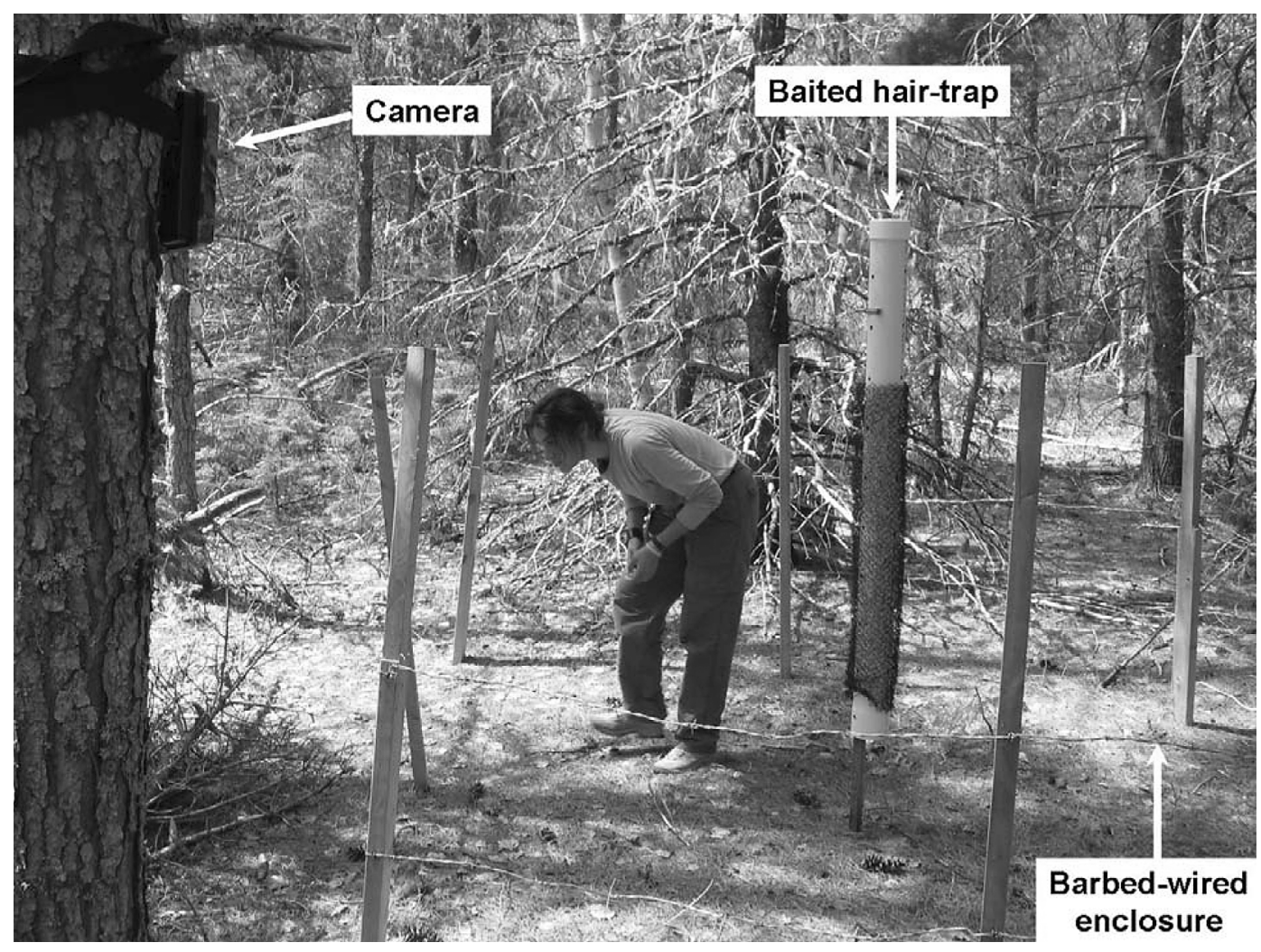

FIGURE 2: Experimental design for Cougar detection, a passive method combining a baited hair-trap (central post and barbed-wired enclosure) protocol and a camera-trap (upper left corner, strapped on a tree).

A volume of $15 \mu \mathrm{L}$ contained $100-500 \mathrm{ng}$ template DNA, $1 \times$ reaction buffer, $1.5 \mathrm{mmol}$ (millimoles) $\mathrm{MgCl}_{2}$, $0.3 \mathrm{mmol}$ each primer, $250 \mathrm{mmol}$ dNTPs and $1 \mathrm{U}$ Taq polymerase. After initial incubation at $94^{\circ} \mathrm{C}$ for 2 minutes, 40 cycles of PCR were performed at $94^{\circ} \mathrm{C}$ for 1 minute, $53^{\circ} \mathrm{C}$ for 1.5 minutes, $72^{\circ} \mathrm{C}$ for 1.5 minutes, and $72^{\circ} \mathrm{C}$ for 10 minutes. Results were then visualized on a $2.0 \%$ agarose gel and compared to 20 species from the six families cited above. A second amplification of $600 \mathrm{bp}$ of a specific region of the $16 \mathrm{~S} \mathrm{mtDNA}$ was then conducted according to the protocol detailed by Mills et al. (2000). Restriction enzymes HaeIII, HpaII, and $R s a \mathrm{I}$ then digested PCR products at $37^{\circ} \mathrm{C}$ during 12 hours, and results were visualized on $2.5 \%$ agarose gel. Since restriction enzymes produce species-specific patterns, it was then possible to distinguish Cougar from other felid species.

\section{Results}

\section{Baited hair traps}

A total of 207 samples was collected from hair traps (Table 1). MtDNA analyses conducted on hair samples collected in 2003 revealed that two samples collected in FNP were Cougar hair. The first hair sample was found near the main road entering the park
TABLE 1. Number of hair samples collected per location and per year for 2003-2006.

\begin{tabular}{lrrrr}
\hline \hline Location & \multicolumn{4}{c}{ Sampling periods } \\
\cline { 2 - 5 } & 2003 & 2004 & 2005 & 2006 \\
\hline KNP & 0 & 6 & 15 & 7 \\
FNP & 29 & 34 & 49 & 23 \\
CBHNP & 1 & 3 & 17 & 16 \\
MIRAM & $-*$ & - & 6 & 1 \\
Total & 30 & 43 & 87 & 47 \\
\hline \hline
\end{tabular}

*Baited hair-traps and camera-traps were installed in the Miramichi (MIRAM) area during the fall of 2004

(i.e., Kinnie Brook), in a young Red Spruce (Picea rubens) and Balsam Fir (Abies balsamea) stand (6 to $12 \mathrm{~m}$ high, canopy closure of 70\%). Ground cover mostly consisted of Sphagnum spp. and Bunchberry (Cornus canadensis). The other hair sample was found in the northern area of the park, along an old logging trail (i.e., Big Dam trail) relatively overgrown with Red Spruce, Balsam Fir and birch (Betula spp.). In this case, trees were taller (12-20 m) but canopy closure was only 40-50\%. A 6-m-high understory composed of Balsam Fir, Red Spruce and White Birch (Betula papyrifera) allowed no ground cover other than birch leaves. 


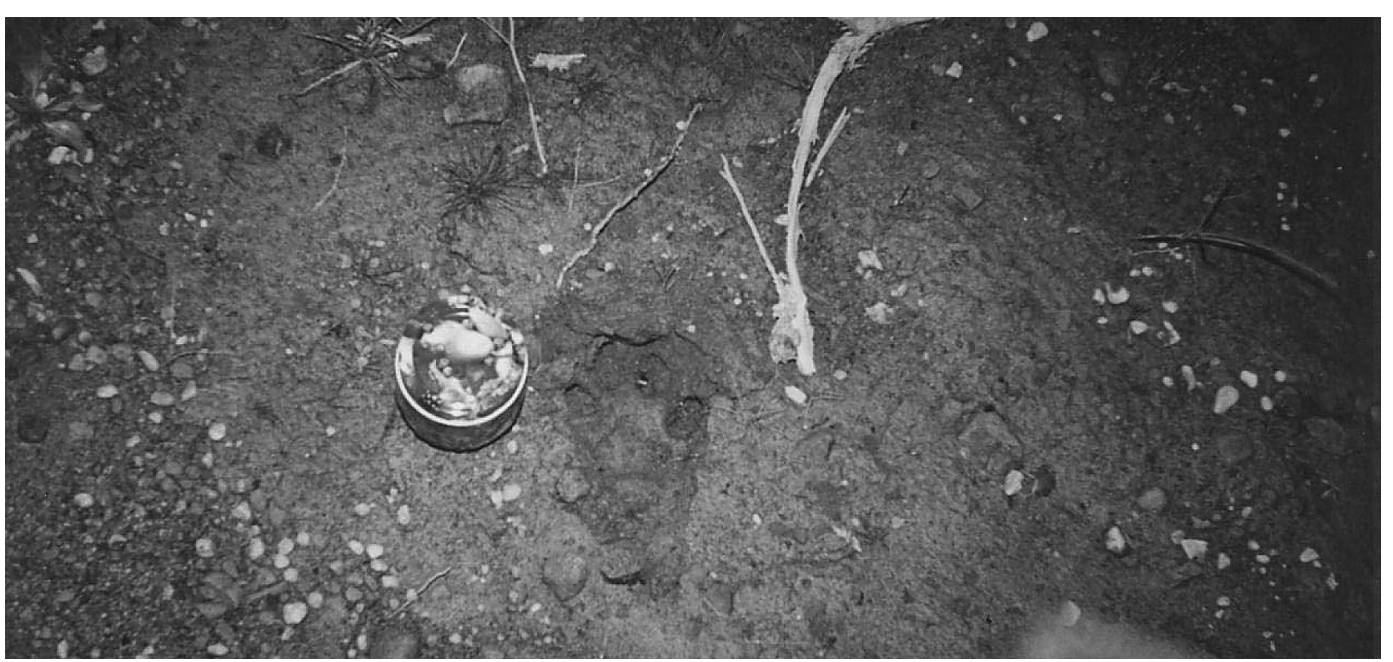

FIGURE 3. Footprint found west of Blackville (GPS coordinates (NAD 1983): 20N0724671; UTM 5188486), New Brunswick, Canada (22 September 2004). Picture provided by P. Boucher. Box (to left of footprint) diameter: $8.5 \mathrm{~cm}$.

Further DNA sequencing revealed that the two hair samples came from two distinct animals, i.e., a North American specimen and a South American specimen. Camera-traps were only installed in 2004 , so there is no photographic record of these two individuals. No Cougar hair or picture were collected after the cameras had been installed.

\section{Additional Observation}

Sets of tracks can also be used to identify species (van Dyke and Broke 1987; Cumberland and Dempsey 1994). A footprint (Figure 3) was photographed in 2004 by three reliable observers in Blackville (southwest of Miramichi, New Brunswick) 15 minutes after they had seen the Cougar at 12:25 PM and watched it for several seconds as it was crossing a dirt road $45 \mathrm{~m}$ from them. This track was examined by experts and declared not to be of a Coyote (F. Scott and P. G. Crawshaw Jr., personal communication).

\section{Discussion}

Cougar detection program for the Maritimes

Hair-traps and camera-traps are alternative and convenient non-invasive methods that are cost- and timeefficient techniques for animal surveys (Carbone et al. 2001). After four years of permanent cougar monitoring in the Maritimes, the amount of field data keeps increasing. As suggested by Cardoza and Langlois (2002), it would be valuable to establish a systematic monitoring program supervised by an expert team for the Eastern Cougar population, especially for the provinces where the status of this species is indeterminate. This would allow collection of a series of undisputable physical evidence (Cardoza and Langlois 2002; Maehr et al. 2003). As mentioned by others, the probability of proving the presence of a species which has no es- tablished viable populations in a given area is almost nil (Broke and van Dyke 1985).

DNA hair analyses confirmed that two Cougars occurred in southern NB in 2003. Additional data (e.g., individual genetic haplotype) are nonetheless crucial to better understand the status of the species in this part of its range. One of the individuals detected in Fundy turned out to be a South American animal, recalling the Chilean specimen shot in Abitibi, Québec, in May 1992 (Jolicoeur et al. 2006). This may indicate that a few scattered escapees from zoos or captives released by private owners remain (Stocek 1995). However, the other positive hair sample caught in the Big Dam Trail in FNP was from an animal of North American origin. This opens up a range of possibilities. In eastern North America, estimates of the number of escaped captives kept increasing during the last 30 years. In Pennsylvania for instance, McGinnis (1996) reported only 31 cougars held in captivity in 1979, among which four or five eventually escaped. Then, less than 20 years later, according to J. Seidensticker (cited in Scott $\left.1998^{*}\right)$, there was an increase of $640 \%$ in the number of licensed private Cougar owners. This dramatic increase in the number of captive individuals probably suggests many more escapees of North and South American origins. Further DNA identifications will enable researchers to shed more light on this question. The fact that cougars are efficient colonizers (Nero and Wrigley 1977) with large home ranges (Seidenticker et al. 1973) ensures that the debate about the potential presence of animals in eastern Canada continues. Reported cougars may be transients, escapees or members of a remnant population, but they could act as dispersers for the (re)establishment of viable populations in eastern Canada (Scott 1998*; Maehr et al. 2002). The 
determination of these cats' origin should help define the protection status they deserve.

\section{Acknowledgments}

The authors acknowledge the information provided by F. Scott, M. Mazzolli, P. G. Crawshaw Jr., and J. Dalponte, technical assistance by P.-E. Hébert (KNP), G. Sinclair (FNP), S. Lambert, J. Hudson and L. A Reeves (CBHNP). Comments by J. Tischendorf, H. McGinnis, J. Bridgland, G. T. Campbell and two anonymous reviewers significantly increased the quality of this paper. This project was supported by Parks Canada - Species at Risk Program Grant to L . V.

Documents Cited (marked * in text)

Scott, F. W. 1998. Updated COSEWIC status report on Cougar (Puma concolor couguar) [eastern population] Committee on the Stauts of Endangered Wildlife in Canada (COSEWIC), Ottawa.

van Zyll de Jong, G. G., and E. van Ingen. 1978. Status report on eastern cougar Felis concolor couguar in Canada. COSEWIC, Ottawa.

\section{Literature Cited}

Broke, R. H., and F. G. van Dyke. 1985. Eastern cougars: the verifiability of the presence of isolated individuals versus populations. Cryptozoology 4: 31-49.

Carbone, C., S. Christie, K. Conforti, T. Coulson, N. Franklin, J. R. Ginsberg, M. Griffiths, J. Holden, K. Kawanishi, M. Kinnaird, R. Laidlaw, A. Lynam, D. W. Macdonald, D. Martyr, C. McDougal, L. Nath, T. O'Brien, J. Seidensticker, D. J. L. Smith, M. Sunquist, R. Tilson, and W. N. Wan Shahruddin. 2001. The use of photographic rates to estimate densities of tigers and other cryptic mammals. Animal Conservation 4: 75-79.

Cardoza, J. E., and S. A. Langlois. 2002. The eastern cougar: a management failure? Wildlife Society Bulletin 30: 265273.

Culver, M., W. E. Johnson, J. Pecon-Slattery, and S. J. O'Brien. 2000. Genomic ancestry of the American puma (Puma concolor). Journal of Heredity 91: 186-197.

Cumberland, R. E., and J. A. Dempsey. 1994. Recent confirmation of a cougar, Felis concolor, in New Brunswick. Canadian Field-Naturalist 108: 224-226.

Dickson, B. G., J. S. Jenness, and P. Beier. 2005. Influence of vegetation, topography, and roads on cougar movement in southern California. Journal of Wildlife Management 69: 264-276.

Godin, A. J. 1977. Wild mammals of New England. John Hopkins University, Baltimore.
Goldman, E. A. 1946. Classification of the races of the puma. The puma: mysterious American cat. Reprint. Dover Publications, New York.

Johnson, W. E., and S. J. O'Brien. 1997. Phylogenetic reconstruction of the felidae using 16S rRNA and NADH5 mitochondrial genes. Journal of Molecular Evolution 44: S98-S116.

Jolicoeur, H., A. Paquet, and J. Lapointe. 2006. Sur la piste du couguar (Puma concolor) au Québec, 1955-2005 : analyse des rapports d'observation. Le Naturaliste canadien 130: 49-58.

Maehr, D. S., E. D. Land, D. Shindle, O. L. Bass, and T. S. Hoctor. 2002. Florida panther dispersal and conservation. Biological Conservation 196: 187-197.

Maehr, D. D., M. G. Kelly, C. Bolgiano, T. Lester, and H. McGinnis. 2003. Eastern cougar recovery is linked to the Florida panther: Cardoza and Langlois revisited. Wildlife Society Bulletin 31: 849-853.

McGinnis, H. J. 1996. Reports of pumas in Pensylvania, 1890-1981. Proceedings of the $1^{\text {st }}$ Eastern Cougar Conference, 1994. American Ecological Research Institute AERIE, Fort Collins.

Mills, L. S., K. L. Pilgrim, M. K. Schwartz, and K. McKelvey. 2000. Identifying lynx and other North American felids based on MtDNA analysis. Conservation Genetics 1: 285288.

Nero R. W., and R. E. Wrigley. 1977. Status and habits of the Cougar in Manitoba. Canadian Field-Naturalist 91: 28-40.

Parker, G. R. 1998. The eastern panther. Nimbus Publishing, Halifax, Nova Scotia.

Seidensticker, J. C., M. G. Hornocker, W. V. Wiles, and J. P. Messick. 1973. Mountain lion social organization in the Idaho primitive area. Wildlife Monographs number 35.

Stocek, R. F. 1995. The Cougar, Felis concolor, in the Maritime Provinces. Canadian Field-Naturalist 109: 19-22.

Taylor, S. K., C. D. Buergelt, M. E. Roelke-Parker, B. L. Homer, and D. S. Rotstein. 2002. Causes of mortality of free-ranging Florida panthers. Journal of Wildlife Diseases 38: $107-114$

van Dyke, F. G., and R. H. Broke. 1987. Sightings and track reports as indices of mountain lion presence. Wildlife Society Bulletin 15: 251-256.

Weaver, J. L., P. C. Paquet, and L. F. Ruggiero. 1996. Resilience and conservation of large carnivores in the Rocky Mountains. Conservation Biology 10: 964-976.

Woodley, S., G. Forbes, and A. Skibicki. Editors. 1998. State of the Greater Fundy Ecosystem. Greater Fundy Research Group, University of New Brunswick, Fredericton, New Brunswick. 215 pages.

Received 19 December 2005

Accepted 27 December 2006 